\title{
MASS CONCENTRATIONS AND ELEMENTAL COMPOSITION OF URBAN ATMOSPHERIC AEROSOLS IN ADDIS ABABA, ETHIOPIA
}

\author{
G. Gebre ${ }^{1}$, Z. Feleke ${ }^{2 *}$ and E. Sahle-Demissie ${ }^{3}$ \\ ${ }^{1}$ Environmental Science Program, Addis Ababa University, P. O. Box 1176, Addis Ababa, \\ Ethiopia \\ ${ }^{2}$ Department of Chemistry, Addis Ababa University, P. O. Box 1176, Addis Ababa, Ethiopia \\ ${ }^{3}$ Office of Research and Development, National Risk Management Research Laboratory, OH \\ 45268, USA
}

(Received December 13, 2009; revised June 4, 2010)

\begin{abstract}
Aerosol samples were collected from 22 February 2008 to 15 April 2008 and 17 June 2008 to 23 July 2008 in urban and peri-urban areas of Addis Ababa, Ethiopia, with the aim to assess the spatial and temporal aspects of total suspended particulate (TSP) and particulate matter with aerodynamic diameter less than $10 \mu \mathrm{m}$ $\left(\mathrm{PM}_{10}\right)$ and their composition in terms of metallic elements. Sixty six filter samples were collected from seven distinct sites using I.O.M. multi fraction dust samplers and fiber glass filter papers. The mass of each particulate matter sample was measured gravimetrically and the composition of $\mathrm{PM}_{10}$ samples was analyzed using ICPOAES and SEM-EDAX. The concentration of TSP was in the range of $17-556 \mu \mathrm{g} / \mathrm{m}^{3}$ and that of PM 10 was in the range of $17-285 \mu \mathrm{g} / \mathrm{m}^{3}$. The highest TSP and $\mathrm{PM}_{10}$ peak values were observed in February 2008 at two sites, whereas the lowest TSP and PM $_{10}$ values were observed in June and July 2008 at two sites. The mean TSP concentration surpassed the WHO safe guideline value of $150 \mu \mathrm{g} / \mathrm{m}^{3}$ and $79 \%$ of the $\mathrm{PM}_{10}$ values were below the WHO guideline value. The $\mathrm{PM}_{10}$ to TSP mass ratio was in the range 0.26-0.59 and $\mathrm{PM}_{10}$ mass contributed about $39 \%$ to the TSP mass. The average element concentration in $\mathrm{PM}_{10}$ filter sample was in the order of $\mathrm{Ca}>\mathrm{Na}>\mathrm{K}>$ $\mathrm{Zn}>\mathrm{Sb}>\mathrm{B}>\mathrm{Al}>\mathrm{V}>\mathrm{Mg}>\mathrm{S}>\mathrm{Fe}$. All the analyzed elements contributed about $0.1 \%$ to the $\mathrm{PM}_{10}$ mass. SEMEDAX analysis of $\mathrm{PM}_{10}$ samples showed that $\mathrm{Si}, \mathrm{Al}, \mathrm{Na}, \mathrm{Zn}, \mathrm{Ba}, \mathrm{K}$ and $\mathrm{C}$ were the predominant species. Crustal materials contributed 76-95\% of the filter mass, and $\mathrm{C}$ and $\mathrm{Cu}$ represented 5-24\%. The size distribution of aerosol particles as derived from SEM analysis was in 0.43-9.3 $\mu \mathrm{m}$ range.
\end{abstract}

KEY WORDS: TSP, $\mathrm{PM}_{10}$, Metal analysis, Atmospheric aerosol, Addis Ababa, Ethiopia

\section{INTRODUCTION}

Addis Ababa is the capital city of Ethiopia and it is a fast-growing urban area in which air quality is affected mainly by increased vehicle emissions, traffic road dust, industrial developments, construction activities, and overall land use practices. Air quality has become a serious concern due to geographical and climatic condition of the city and high air pollutant emissions in the area [1]. There is growing concern for public health, although detailed toxicological and epidemiological studies are non-existent.

The city has a population of more than 2.7 million with a growth rate of $3.8 \%$ [2]. The main rainy season extends from mid June to early September and the dry season extends from October to early June. The small rains, which are short lived and less intense are experienced in March and April. Based on this seasonality, air pollution is likely worst between October and February, when precipitation is minimal and high-pressure systems can cause stagnation episodes [1]. In Ethiopia, limited measurement of air pollutants is available [1]. However, air quality study in Addis Ababa provides only a snapshot of particulate pollutants in dry season (in January/February of 2004) and focused on the major streets. Overall, there is limited information on gaseous pollutants which is mainly focused on ambient $\mathrm{CO}$ level $[1,3]$.

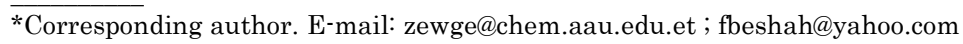


Considerable air pollution occurs in large cities throughout the world [4]. It has great impact on the local environment (e.g. on biosphere, buildings and materials) and visibility, and can even influence the surrounding rural areas. The pollution also affects many people inasmuch as these urban areas usually accommodate a large number of inhabitants. The coincidence of the concentrated pollution sources, dense population and/or some times unfavorable geographical and climatic conditions may multiply its adverse effects in particular. Although air pollution and smog problems are very complex, a small set of compounds has been identified as major contributors to the phenomenon. They are called criteria pollutants, and serve as indicators of the air quality in pollution control policy. The criteria pollutants usually include $\mathrm{NO}$ and $\mathrm{NO}_{2}$, $\mathrm{SO}_{2}, \mathrm{CO}$, tropospheric $\mathrm{O}_{3}$, total or size-fractionated suspended airborne particulate matter [5]. Research into the criteria pollutants and their synergism has revealed that it is the elevated levels of airborne particles that are mainly responsible for the increased health risks of inhabitants in large cities [5-7]

Particulate matter of aerodynamic diameter less than $10 \mu \mathrm{m}$, and especially that less than 2.5 $\mu \mathrm{m}$, has been found to be associated with urban health problems [8]. Many epidemiological studies show that atmospheric aerosols may produce adverse health effects, with recent studies revealing that coarser atmospheric particles are more related to respiratory diseases, whereas the finest particles seem to affect the cardio-vascular system [9-12]. Atmospheric aerosols, especially the sub micrometer-sized particles, also affect the Earth's climate both directly through scattering and absorption of solar radiation and indirectly by acting as cloud condensation nuclei, CCN [13].

Particulate matter pollution arises both from natural and anthropogenic sources. Although the dominant origin of atmospheric aerosols on a global scale is natural [13], in urban areas the main source of atmospheric PM is road traffic [14-16], with diesel vehicles in particular being associated with higher emissions of fine and ultrafine particles [14, 17, 18], exceeding up to 10100 times those from gasoline vehicles in terms of mass, and up to 105 times in terms of number concentration [17].

Recently in the developed world (Europe and North America) the concentration of particulate matter (PM) has been decreasing due to modern technology employed for pollution prevention and control. However, in some developing countries, such as China and India, the PM concentration has been on the rise due to energy-intensive activities and a similar problem may be expected in African cities. With regard to data on PM and its composition in Africa, extensive work has been done on biomass burning smoke, mainly from savanna fires during dry season campaign [19].

The atmospheric aerosols can be characterized from a number of viewpoints, i.e. by number or mass concentration, chemical composition (elemental, organic and ionic), speciation, size distribution, morphology of the particles and by their source types. Many of these properties are, moreover, interdependent. In addition, the characteristics may display a pronounced variability in time and space due to the wide variety in formation, dynamic transformation, transportation and removal processes of the aerosols. The situation is particularly complicated in highly polluted (urban) air sheds.

In the past 20 years, the composition and sources of $\mathrm{PM}_{10}$ aerosols in various environments have been studied in a number of papers [20]. Considerable concerns have arisen on the extent of the pollution, particularly by the presence of metals in airborne particles. These observations lead to investigation of their origin with the development of characterization or speciation studies, using, for example, particle-induced X-ray emission (PIXE) [21], spectroscopy and Xray fluorescence [22], chemical analysis, and scanning electron microscopy coupled to an energy-dispersive X-ray spectrometer (SEM-EDAX) [23]. Highly sensitive and non-destructive techniques are useful for the direct analysis of particles collected on filters. 
The aim of this study is to assess the spatial and temporal aspects of TSP and $\mathrm{PM}_{10}$ with emphasis on metal characterization by using ICP-OAES and SEM-EDAX. Electron microscopy may provide valuable information on the morphology, composition, sources, and transformations of atmospheric aerosols. Mass concentration of TSP and $\mathrm{PM}_{10}$ in ambient air was also measured for the wet and dry seasons. The result of this study will be useful to understand the status of ambient air quality in Addis Ababa and also provide some information that would be useful for further investigation.

\section{EXPERIMENTAL}

Sampling sites

This research was conducted between 22 February 2008 and 15 April 2008 (for the dry season), and 17 June 2008 to 23 July 2008 (for the wet season). Sampling sites were selected to represent typical and important ambient air quality situations in Addis Ababa (Table 1).

Table 1 Description of sampling sites

\begin{tabular}{|l|c|c|}
\hline Sample site & Sample code & * Geographical location of sampling points \\
\hline Department of Nefas Silk Lafto Police & NSLP & 37 P 0473000; UTM 0991000 \\
\hline Kolfe Keraniyo Custom Check & KoKCC & 37 P 0464338; UTM 0991481 \\
\hline Kotebe Waste Water Treatment & KWWT & 37 P 0483063; UTM 0991418 \\
\hline Kaliti Substation & KSUB & 37 P 0473000; UTM 0981000 \\
\hline Aste T/Giorgis Elementary \& Junior School & ATSE & 37 P 0473000; UTM1,001,000 \\
\hline Addis Ababa Stadium & STAD & 37 P 0473072; UTM 0996070 \\
\hline COMESA Leather Technology Institute & COLTI & 37 P 0472704; UTM 0981962 \\
\hline
\end{tabular}

"Data in column 3 represents linear distance of X (37 P 0473000) and Y (UTM 0991000) coordinates of the sampling points. $37 \mathrm{P}$ (zone) is a code where a country is located and UTM - Universal Transfer Maker which is a term for satellite navigation system.

Seven distinct sites were selected for ambient aerosols sampling. The sites were chosen systematically so that they represent different socio-economic practices in the urban and periurban areas that influence ambient air quality of Addis Ababa (Figure 1). Consequently, topographic map of the city was used to identify the sites taking in to consideration of both geographic distance and land use practices. The sampling sites are located between 5 and $10 \mathrm{~km}$ from the geographic center of Addis Ababa which is Nefas Silk Lafto Sub-City Police Department (NSLP). The sampling points within $5 \mathrm{~km}$ distance are associated with high socioeconomic activities (urban environment) and those points at $10 \mathrm{~km}$ distance (peri-urban area) have relatively low level of human interventions.

The identified sampling sites include Nefas Silk Lafto Sub-City Police Department (NSLP), Kolfe Keraniyo Custom Check Point (KoKCC), Kotebe Waste Water Treatment Plant (KWWT), Kaliti Substation (KSUB), Atse T/Giorgis Elementary and Junior School (ATSE), Addis Ababa Stadium (STAD) and COMESA Leather Technology Institute (COLTI). Detailed description of the sampling sites is given below.

Nefas Silk Lafto Sub-City Police Department (NSLP) is located at the geographic centre of Addis Ababa locally known as "Gotera". It is surrounded by vehicle repair shops, residential houses, commercial firms, fuel depot, Addis Ababa cement factory and Moha Nefas Silk Soft Drinks Factory. Gotera road complex has been under construction while the samples were collected, and the crossroad is one of the most congested traffic areas in the metropolitan.

Kolfe Keraniyo Custom and Security Check Point (KoKCC) is located in the south western part of the city. It is situated in a less congested residential neighborhood that was surrounded by different urban activities. The major land use activities around the site are Kolfe Keraniyo 
Custom Check Point, a camp for Federal Police Force, a kindergarten, residential houses, a dairy farm and a wooded area covered by few eucalyptus trees.

Kotebe Waste Water Treatment Plant site (KWWT) is located in the eastern part of Addis Ababa which is found in Bole Sub-City. The major land uses around the site include: a waste water treatment plant, quarries (construction material mining and crushing activities) and very small agricultural practices and an asphalt road (that connects Yerer with CMC and Akaki subcity) was under construction. The wastewater treatment plant occupied an area of 13.7 hectares which is practices sludge oxidation on a drying bed.

Kaliti substation site (KSUB) is one of Ethiopian Electric Power Corporation (EEPCO) substation which is located in the southern part of the city. The major land use around the site is an agricultural land, and a small village. A mountain peak is located on the western part of the site. This site is considered as a background site.

ATSE site is located in the northern part of Addis Ababa. The land use that is surrounding the sampling site include Atse T/Giorgis Junior and Secondary School, less congested residential houses, a cemetery, a waste water transfer station and a vegetation cover at the upper part.

STAD site is located at the central part of Addis Ababa. The site is surrounded by various forms of socio economic activities including commercial, recreational, service delivery, and high traffic flow. The site is one of the major public attraction (or popular) spots in the city.

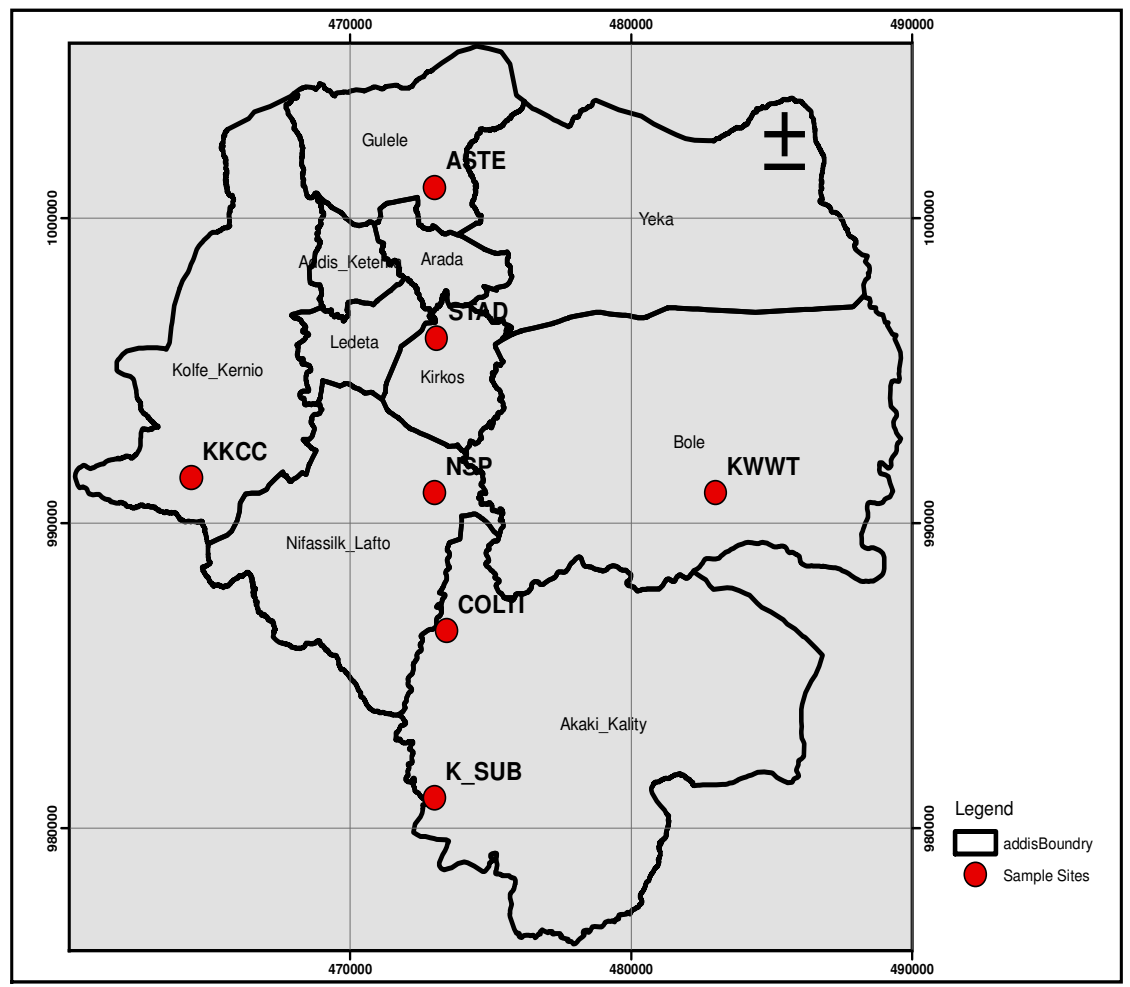

Figure 1. Map showing the TSP and $\mathrm{PM}_{10}$ sampling sites. 
COLTI sampling site is located in the southern part of Addis. The site was designated as an industrial zone in the revised master plan of Addis Ababa. Consequently, the major land use practice of the site is dominated by manufacturing and processing industries. These include soap, metal works, paint, tanneries, concrete block manufacturing, coffee bean preparation, construction activities, a corrugated iron manufacturing industry and road construction materials processing which are some to be mentioned. Sample from this site was collected inside COMESA Leather Technology Institute compound.

\section{Sampling methods}

The sampling unit comprised of portable Institute of Occupational Medicine (IOM) multi fraction dust samplers (made from conductive plastic), tygon hose pipes, battery-operated Universal Air Sampling Pump (SKC 224-PCTX4 Model, SKC Ltd, UK). The samplers were placed at $1.75 \mathrm{~m}$ above ground level (Figure 2). The particulate sample collection system was equipped with a vacuum pump, an internal flow regulator, a timer and air flow calibration unit. Air flow calibration was carried out prior to the commencement of sampling and during the course of sampling. Air flow rate was adjusted to 2.0 liters per minute for TSP and 2.2 liters per minute for the $\mathrm{PM}_{10}$ as recommended by the manufacturer.

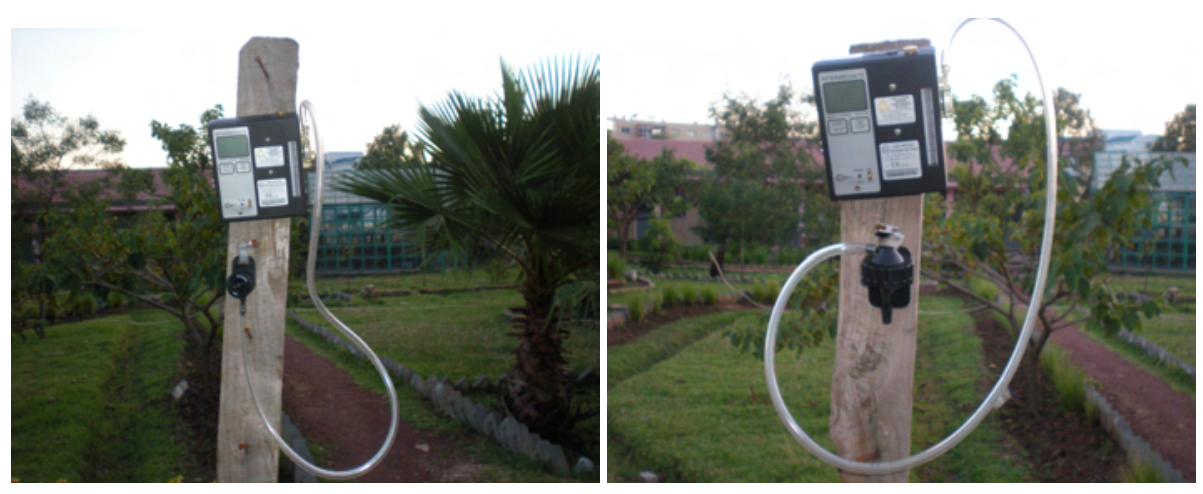

Figure 2. Sampling set up for TSP (left) and $\mathrm{PM}_{10}$ (right).

Samples were collected continuously for $24 \mathrm{~h}$. A total of sixty six $\mathrm{PM}_{10}$ and TSP samples were collected for analysis. Of these, thirty eight were for the dry season, and twenty eight were for wet season. Each filter paper was oven dried, weighed and stored in desiccator before and after sampling until analysis. The filter papers (Whatman ${ }^{\circledR}$, Whatman International Ltd, Maidstone, England) were placed in static-free plastic cassettes for safe transportation. The cassette was fixed inside the samplers, and then after sampling was complete, the unit was removed and preserved for further analysis.

\section{Analytical methods}

The mass of each PM sample was measured gravimetrically. The filters were oven dried at $95 \pm 5$ ${ }^{\circ} \mathrm{C}$ for $2.5 \mathrm{~h}$ and weighed prior to and at the end of each sample collection. $\mathrm{PM}_{10}$ and TSP filters were collected on a fiber glass filters with $25 \mathrm{~mm}$ diameters. The filter samples were weighed using analytical balance with $0.001 \mathrm{mg}$ sensitivity (AT 250, Mettler-Toledo, USA). 
Blank filters were transported to and from the measurement site together with the exposed samples and were placed into the sampler over the collection period, to allow equilibrium between the filter medium and the ambient air. These filters were used as blanks to be subtracted from identical filters that were used for particulate sampling.

$\mathrm{PM}_{10}$ samples were analyzed in National Risk Management Research Laboratory US EPA, Office of Research and Development Cincinnati, USA. ICP-AES was used to analyze crustal and trace metals found in the filter mass while SEM-EDAX was used to determine the size distribution and composition of particulate matter.

Selected $\mathrm{PM}_{10}$ and blank filter samples were analyzed for elements using standard method recommended by USEPA. Inductively Coupled Argon Plasma (ICP) Trace Analyzer Emission Spectroscopy (Optima 3000 Perkin-Elmer Corporation, Nerwalk, Connecticut 06859-0010) was used for elements speciation following acid extraction of filter samples. The samples were extracted in plastic vials using $10 \mathrm{~mL}$ of $4 \%$ nitric acid and were sonicated for $3 \mathrm{~h}$. The acid solutions were decanted from the filter samples and analyzed using ICP. Filter blanks levels for all elements were negligible as compared with the levels in the PM samples.

Filter samples were further examined to determine the chemical composition of inorganic crystalline particulate matter using scanning electron microscope SEM JOEL-6490LV coupled with Oxford X-Act EDS system. The instrument allowed observation of particles down to 3.5 $\mathrm{nm}$ level. In general, 20 and $30 \mathrm{keV}$ beam was applied on the particles to get the image of particulate samples.

\section{RESULTS AND DISCUSSION}

\section{Mass concentration}

Figure 3 shows temporal and Figure 4 shows spatial variation of TSP and $\mathrm{PM}_{10}$ at the sampling sites, respectively. As can be seen, the weight of particulate matter varied significantly during different sampling period for the same site. The mean TSP mass concentration for the overall sampling duration was $195 \pm 141 \mu \mathrm{g} / \mathrm{m}^{3}$. The peak value was $556 \mu \mathrm{g} / \mathrm{m}^{3}$ (February 2008 at NSLP site) and the lowest mass concentration was $17 \mu \mathrm{g} / \mathrm{m}^{3}$ (June 2008 at Kaliti sub-station). It was also noted that the mean TSP concentrations of dry and wet season were $304 \pm 102 \mu \mathrm{g} / \mathrm{m}^{3}$ and $75 \pm 5 \mu \mathrm{g} / \mathrm{m}^{3}$, respectively.

High TSP value may be attributed to the release of aerosols from road construction, paved and unpaved roads around the sampling site. It can be seen that TSP mass concentration declined starting from the end of March 2008 which is the beginning of rain during this particular year. This indicates the significance of scavenging of atmospheric aerosols by rain.

The mean mass concentration of $\mathrm{PM}_{10}$ was $80 \pm 61 \mu \mathrm{g} / \mathrm{m}^{3}$. The highest peak value was 285 $\mu \mathrm{g} / \mathrm{m}^{3}$ (observed in March 2008 at KWWT site) and the lowest value was $17 \mu \mathrm{g} / \mathrm{m}^{3}$ (observed in July 2008 at COLTI site). The mean $\mathrm{PM}_{10}$ mass for dry season was $107 \pm 68 \mu \mathrm{g} / \mathrm{m}^{3}$ and that of wet season was $43 \pm 21 \mu \mathrm{g} / \mathrm{m}^{3}$. High value for dry season may be attributed to the emission of dust particles from paved and unpaved road and incomplete products of fossil fuel combustion, biomass and waste burning activities around the sampling site. Low $\mathrm{PM}_{10}$ value for wet season may be due to scavenging by rain and low level of dust emissions from the paved and unpaved roads around the sample sites. It is also noted that the mean mass concentration was 2 times lower and higher than that of the dry and wet seasons, respectively.

The higher PM mass concentrations during the dry season are likely due to secondary aerosol formation from photochemical reactions $[21,24]$ and also due to absence of scavenging by rain droplets. However, an assessment of secondary aerosol formation and the collection, identification, and measurement of secondary aerosols precursor's gases was not done in this study. No clear relationship was observed between the minimum temperature and the measured mass concentration. 
Figure 3 shows that all sites except KWWT have $\mathrm{PM}_{10}$ mass concentration below the 24-h Ethiopian EPA and WHO guideline value of $150 \mu \mathrm{g} / \mathrm{m}^{3}$. However, the fact that $\mathrm{PM}_{10}$ concentrations approaching $150 \mu \mathrm{g} / \mathrm{m}^{3}$ at five sites suggest that violation of the 24-h guideline value may also be possible. The result also shows that the annual average $\mathrm{PM}_{10}$ guideline value $\left(50 \mu \mathrm{g} / \mathrm{m}^{3}\right)$ has been violated at several sites. However, the long rainy season (July-September) would significantly lower the $\mathrm{PM}_{10}$ concentration, which may help to keep the annual average low. $\mathrm{PM}_{10}$ concentrations ranged between 35 and $97 \mu \mathrm{g} / \mathrm{m}^{3}$, which are lower than what was observed in this study [1]. The difference in results may be due to variation in sampling methodologies. The previous researcher used portable Airmetrics, MiniVol samplers to monitor the concentration of $\mathrm{PM}_{10}$ in the ambient air of Addis Ababa.

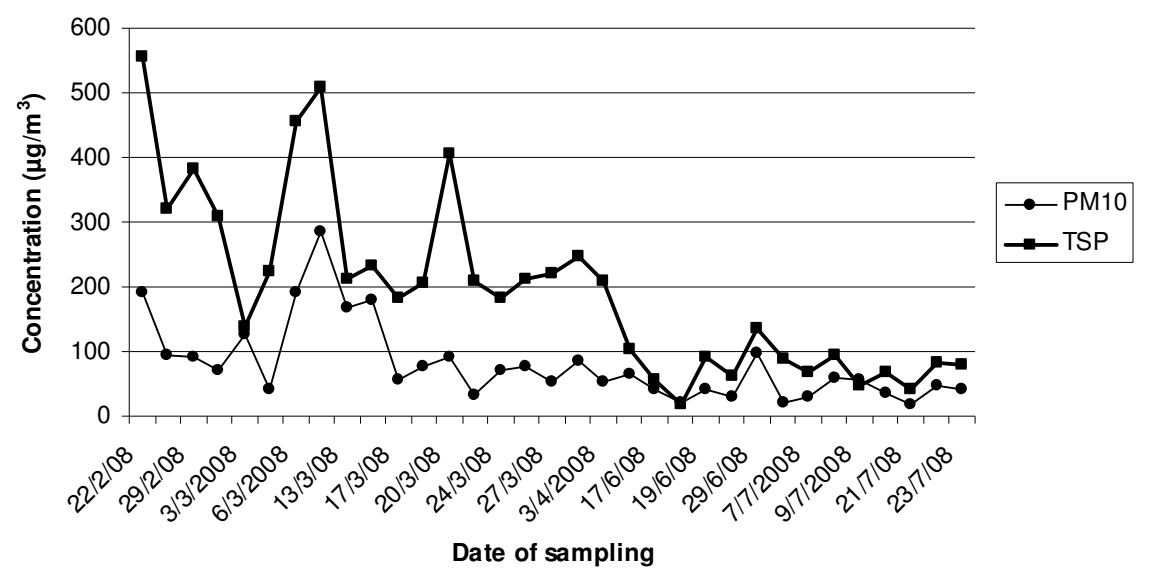

Figure 3. Temporal variations of $\mathrm{PM}_{10}$ and $\mathrm{TSP}\left(\mu \mathrm{g} / \mathrm{m}^{3}\right)$.

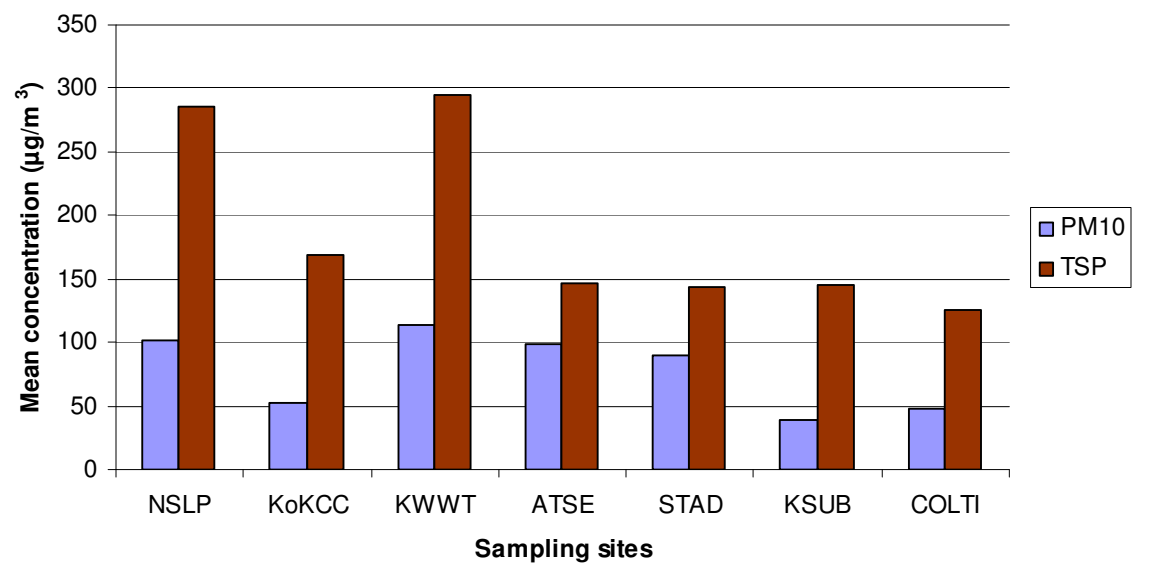

Figure 4. Spatial variations of $\mathrm{PM}_{10}$ and $\mathrm{TSP}\left(\mu \mathrm{g} / \mathrm{m}^{3}\right)$.

Comparison of $\mathrm{PM}_{10}$ with TSP mass concentration is shown in Figure 4. The $\mathrm{PM}_{10}$ to TSP mass ratio was between 0.26 and 0.67 . The result shows that $\mathrm{PM}_{10}$ contributed approximately $42 \%$ to the TSP mass concentration. The remaining portion may be attributed to particulates

Bull. Chem. Soc. Ethiop. 2010, 24(3) 
with an aerodynamic size of greater than 10 micron. The result indicates that both fine and coarse particulates contributed to atmospheric aerosol mass concentration of collected filter mass. Wojas and Almquist found out that $\mathrm{PM}_{2.5}$ mass contributed approximately $95 \%$ to $\mathrm{PM}_{10}$ while $>60 \%$ to TSP [24]. Similar studies conducted by other researchers [25] indicated that $\mathrm{PM}_{10}$ contributed about $75 \%$ of TSP mass. The relatively low contribution of $\mathrm{PM}_{10}$ to the TSP indicating that the emission of fine particulates is low as compared to other big cities.

Coarse particles are linked with disease and death. Lippmann et al. [26] attempted to identify components of particulate matter and other air pollution mixtures that were associated with excess daily deaths and hospital admissions of the elderly in the Detroit metropolitan area. The researchers reported that deaths from respiratory diseases were associated with $\mathrm{PM}_{10}$ and total suspended particulates. They also found that relative risks of the coarse particle fractions were similar to those for $\mathrm{PM}_{2.5}$, and even higher in the case of ischemic heart disease and stroke.

\section{Elemental composition of $P M_{10}$}

ICP-AES Analysis. The average elements concentration of $\mathrm{PM}_{10}$ at sampling sites is shown in Table 2. Although analysis of filter samples was made for 22 elements, those elements, which are detected, are indicated in the table. Crustal elements including $\mathrm{Al}, \mathrm{Ca}, \mathrm{Fe}, \mathrm{Mg}, \mathrm{Na}, \mathrm{Zn}$ and $\mathrm{K}$ were the predominant species and the concentrations of these elements exceed $1 \mu \mathrm{g} / \mathrm{m}^{3}$ in most cases.

It is noted that calcium was the most abundant species. The highest and lowest peak value of calcium was $91.1 \pm 77.6$ and $17.1 \pm 13.5 \mu \mathrm{g} / \mathrm{m}^{3}$, which were observed at KoKKC and STAD sites, respectively. The least abundant crustal species was strontium $0.03 \pm 0.01 \mu \mathrm{g} / \mathrm{m}^{3}$ which was observed at NSLP, KSUB, ATSE and STAD sites. In general the concentration of elements is in the order of $\mathrm{Ca}>\mathrm{Na}>\mathrm{K}>\mathrm{Zn}>\mathrm{Sb}>\mathrm{Al}>\mathrm{Mg}>\mathrm{B}>\mathrm{Fe}>\mathrm{Mg}$. Paved and unpaved road dust is the major sources of $\mathrm{Ca}, \mathrm{Al}, \mathrm{Fe}, \mathrm{Mg}, \mathrm{Zn}, \mathrm{Na}$, and $\mathrm{K}$.

Table 2 compares trace elements concentration of $\mathrm{PM}_{10}$ samples at different sites. The trace metals that were identified include $\mathrm{Cr}, \mathrm{Ni}, \mathrm{Li}, \mathrm{Co}, \mathrm{Cu}$, and $\mathrm{V}$. It was observed that $\mathrm{Cr}$ is identified at all sampling sites. The highest mean value was $1.06 \pm 0.26 \mu \mathrm{g} / \mathrm{m}^{3}(\mathrm{KWWT})$ and the lowest was $0.297 \pm 0.295 \mu \mathrm{g} / \mathrm{m}^{3}$ (KoKCC). Comparison of the value with a previous study conducted in Bangladesh indicates that, $\mathrm{Cr}$ concentration of Addis Ababa is much lower than that of Dhaka $\left(25.2 \pm 12.7 \mu \mathrm{g} / \mathrm{m}^{3}\right)$ and Rajshahi $\left(9.34 \pm 5.44 \mu \mathrm{g} / \mathrm{m}^{3}\right)$ [27]. Co was identified at four sampling sites. The highest mean value was observed at STAD $\left(0.17 \mu \mathrm{g} / \mathrm{m}^{3}\right)$ and the lowest value was obtained at NSLP site $\left(0.11 \mu \mathrm{g} / \mathrm{m}^{3}\right)$. Cu was also identified in all sampling sites. The highest and the lowest peak values were $0.11 \pm 0.06 \mu \mathrm{g} / \mathrm{m}^{3}$ (observed at STAD site) and $0.008 \pm 0.007 \mu \mathrm{g} / \mathrm{m}^{3}$ (KSUB site), respectively. The concentration of $\mathrm{Cu}$ in ambient air of Addis Ababa is lower than that of Dhaka $\left(13.2 \pm 43.4 \mu \mathrm{g} / \mathrm{m}^{3}\right)$ and Rajshahi $\left(2.58 \pm 1.86 \mu \mathrm{g} / \mathrm{m}^{3}\right)$ [27]. The maximum and minimum concentrations of $\mathrm{Li}$ were $0.17 \pm 0.02 \mu \mathrm{g} / \mathrm{m}^{3}$ (STAD site) and 0.02 $\mu \mathrm{g} / \mathrm{m}^{3}$ (NSLP site), respectively. Similarly, the maximum and minimum concentration of B was $2.73 \pm 0.62 \mu \mathrm{g} / \mathrm{m}^{3}$ (NSLP site) and $1.3 \pm 1.2 \mu \mathrm{g} / \mathrm{m}^{3}$ (STAD site), respectively. Mo was identified at KWWT and STAD sites whereas S was identified at STAD site. This result shows that the concentration of $\mathrm{Ni}$ in Addis Ababa is far below USEPA air quality guideline value of 25 $\mu \mathrm{g} / \mathrm{m}^{3}$. The highest and lowest peak values of $\mathrm{V}$ were $0.02 \pm 0.01 \mu \mathrm{g} / \mathrm{m}^{3}$ (STAD site) and $0.016 \pm 0.007 \mu \mathrm{g} / \mathrm{m}^{3}$ (KoKCC site), respectively. This indicates that the concentration of $\mathrm{V}$ in Addis Ababa is far below the US air quality guideline value of $200 \mu \mathrm{g} / \mathrm{m}^{3}$. The maximum and minimum concentrations of $\mathrm{Sb}$ were $12.4 .7 \pm 0.3 \mu \mathrm{g} / \mathrm{m}^{3}$ (ATSE site) and $0.03 \pm 0.01 \mu \mathrm{g} / \mathrm{m}^{3}$ (STAD site). Comparison among the sampling sites indicates that STAD site has higher sulfur whereas in other sites trace metals concentration is high. Since the trace metals are typically associated with anthropogenic emissions (traffic, combustion of fossil fuels, various industries), their concentration is expected to be higher at sites with more such activities. 
Table 2. Mean elements concentration $\left(\mu \mathrm{g} / \mathrm{m}^{3}\right)$ of $\mathrm{PM}_{10}$ samples.

\begin{tabular}{|l|l|l|l|l|l|l|}
\hline \multirow{2}{*}{ Element } & \multicolumn{5}{|c}{ Elements concentration $\left(\mu \mathrm{g} / \mathrm{m}^{3}\right)$} & of $\mathrm{PM}_{10}$ for different sampling sites \\
\cline { 2 - 7 } & $\mathrm{NSLP}$ & KoKCC & KWWT & KSUB & ATSE & STAD \\
\hline $\mathrm{Al}$ & $3.03 \pm 0.6$ & $2.69 \pm 1.95$ & $3.63 \pm 1.24$ & $2.23 \pm 0.41$ & $2.25 \pm 0.48$ & $1.14 \pm 1.12$ \\
\hline $\mathrm{Ca}$ & $35.1 \pm 18.6$ & $91.1 \pm 77.6$ & $35.3 \pm 18.9$ & $25.7 \pm 0.9$ & $36.7 \pm 23.1$ & $17.1 \pm 13.5$ \\
\hline $\mathrm{Cr}$ & $0.77 \pm 0.21$ & $0.297 \pm 0.295$ & $1.06 \pm 0.26$ & $0.9 \pm 0.15$ & $0.64 \pm 0.04$ & $0.42 \pm 0.29$ \\
\hline $\mathrm{Co}$ & $0.11 \pm 0.02$ & $\mathrm{ND}$ & 0.13 & $\mathrm{ND}$ & 0.14 & 0.17 \\
\hline $\mathrm{Cu}$ & $0.07 \pm 0.07$ & $0.07 \pm 0.076$ & $0.02 \pm 0.00$ & $0.008 \pm 0.007$ & 0.02 & $0.11 \pm 0.06$ \\
\hline $\mathrm{Fe}$ & $1.46 \pm 0.42$ & $1.33 \pm 0.85$ & $2.22 \pm 0.14$ & $0.82 \pm 0.25$ & $0.95 \pm 0.21$ & $0.72 \pm 0.42$ \\
\hline $\mathrm{Li}$ & 0.02 & $0.052 \pm 0.06$ & $0.04 \pm 0.04$ & 0.04 & 0.03 & $0.17 \pm 0.02$ \\
\hline $\mathrm{Mg}$ & $1.12 \pm 0.46$ & $2.4 \pm 2.36$ & $1.74 \pm 0.29$ & $0.97 \pm 0.04$ & $1.32 \pm 0.59$ & $0.85 \pm 0.48$ \\
\hline $\mathrm{Mn}$ & $0.1 \pm 0.01$ & $0.155 \pm 0.13$ & $0.17 \pm 0.02$ & $0.05 \pm 0.01$ & $0.11 \pm 0.01$ & $0.05 \pm 0.02$ \\
\hline $\mathrm{Sr}$ & $0.03 \pm 0.01$ & $\mathrm{ND}$ & $\mathrm{ND}$ & $0.03 \pm 0.00$ & $0.04 \pm 0.02$ & $0.03 \pm 0.02$ \\
\hline $\mathrm{Ti}$ & $0.1 \pm 0.03$ & $0.077 \pm 0.05$ & $\mathrm{ND}$ & $0.06 \pm 0.04$ & $0.07 \pm 0.05$ & $0.03 \pm 0.03$ \\
\hline $\mathrm{Ni}$ & 0.01 & $\mathrm{ND}$ & $\mathrm{ND}$ & $\mathrm{ND}$ & $\mathrm{ND}$ & $\mathrm{ND}$ \\
\hline $\mathrm{Zn}$ & $7.57 \pm 1.76$ & $10.41 \pm 6.78$ & $7.24 \pm 2.15$ & $5.67 \pm 1.21$ & $7.13 \pm 3.6$ & $7.68 \pm 6.28$ \\
\hline $\mathrm{Na}$ & $21.0 \pm 2.8$ & $28.1 \pm 13.8$ & $22.5 \pm 2.7$ & $20.4 \pm 2.4$ & $21.7 \pm 4.7$ & $13.6 \pm 6.3$ \\
\hline $\mathrm{K}$ & $7.4 \pm 1.07$ & $12.3 \pm 9.1$ & $7.67 \pm 1.42$ & $6.46 \pm 0.63$ & $7.4 \pm 1.5$ & $4.89 \pm 2.3$ \\
\hline $\mathrm{B}$ & $2.73 \pm 0.62$ & $2.05 \pm 1.37$ & $2.7 \pm 0.87$ & $1.82 \pm 1.06$ & $1.84 \pm 0.8$ & $1.3 \pm 1.2$ \\
\hline $\mathrm{Sb}$ & $\mathrm{ND}$ & $1.297 \pm 0.53$ & $11.8 \pm 0.3$ & $\mathrm{ND}$ & $12.4 \pm 0.3$ & $0.03 \pm 0.01$ \\
\hline $\mathrm{V}$ & $\mathrm{ND}$ & $0.016 \pm 0.007$ & $\mathrm{ND}$ & $\mathrm{ND}$ & $\mathrm{ND}$ & $0.02 \pm 0.01$ \\
\hline $\mathrm{Mo}$ & $\mathrm{ND}$ & $\mathrm{ND}$ & $1.33 \pm 0.27$ & $\mathrm{ND}$ & $\mathrm{ND}$ & $1.55 \pm 0.63$ \\
\hline $\mathrm{Cd}$ & $\mathrm{ND}$ & $\mathrm{ND}$ & $\mathrm{ND}$ & $\mathrm{ND}$ & $\mathrm{ND}$ & $0.02 \pm 0.007$ \\
\hline $\mathrm{S}$ & $\mathrm{ND}$ & $\mathrm{ND}$ & $\mathrm{ND}$ & $\mathrm{ND}$ & $\mathrm{ND}$ & $10.9 \pm 10.1$ \\
\hline
\end{tabular}

Vegetative burning, residential wood combustion, and cooking are also the sources of $\mathrm{K}, \mathrm{V}$, $\mathrm{Ni}, \mathrm{S}, \mathrm{Co}$ and $\mathrm{B}$ are associated with emissions from motor vehicles, residual oil combustion and incineration [28]. There is no significant difference in mean $\mathrm{Li}, \mathrm{Cu}, \mathrm{Co}, \mathrm{Cr}, \mathrm{Mo}, \mathrm{V}$ and $\mathrm{Ni}$ concentrations between sampling sites, which may indicate that emission sources are spatially distributed. However there is significant difference in $\mathrm{B}, \mathrm{S}$ and $\mathrm{Sb}$ concentration between STAD and other site. This may suggest the existence of specific emission sources, which requires further investigations.

Crustal and trace metals contribute only a very small fraction $(0.04-0.32 \%)$ of the total $\mathrm{PM}_{10}$ mass. The remaining portion may be attributed to organic carbon (OC), elemental carbon (EC), silicon and water-soluble constituent of atmospheric aerosol [28]. Mass concentrations reconstructed from chemical composition indicated that $\sim 35-65 \%$ of the $\mathrm{PM}_{10}$ mass was due to geologically derived material and $\sim 35-60 \%$ was due to OM and EC [1]. Of the crustal and trace metal fraction, the former contributes more than $98 \%$ of the total portion. A comprehensive chemical characterization of $\mathrm{PM}_{2.5}$ and $\mathrm{PM}_{10}$ samples at urban and near rural sites in Switzerland indicated that crustal metals were found to be the predominant species in the coarse fraction [29]. The presence of crustal and trace metals in the present study suggests existence of combination of sources.

Table 3 shows the correlation coefficients of metal species in $\mathrm{PM}_{10}$ mass. Although source apportionment is outside the scope of this research, it is noted that crustal elements such as $\mathrm{Al}$ with $\mathrm{Zn}, \mathrm{Ca}$ with $\mathrm{Mg}$ and $\mathrm{Sr}, \mathrm{Mg}$ with $\mathrm{Mn}$ and $\mathrm{Sr}$ and $\mathrm{Zn}$ with $\mathrm{Na}$ have strong correlation. Similarly $\mathrm{Cr}$ has strong correlation with $\mathrm{S}$ as do $\mathrm{Cu}$ with $\mathrm{B}$ and $\mathrm{B}$ with $\mathrm{V}$. It is also clear from the table that $\mathrm{Ni}$ has strong correlation with $\mathrm{Al}, \mathrm{Ca}, \mathrm{Cr}, \mathrm{Cu}, \mathrm{Fe}, \mathrm{Li}, \mathrm{Mn}, \mathrm{Ti}, \mathrm{Zn}, \mathrm{Na}, \mathrm{K}, \mathrm{B}$ and $\mathrm{Co}$. Strong correlation between elements may suggest the existence of identical emission sources. 
Wojas and Almquist et al. reported that metals such as $\mathrm{Ca}, \mathrm{Co}, \mathrm{Cu}, \mathrm{Fe}, \mathrm{K}, \mathrm{Mg}, \mathrm{Mn}, \mathrm{Mo}, \mathrm{Ni}, \mathrm{Pb}$, $\mathrm{Sb}, \mathrm{Si}$, and $\mathrm{Zn}$ have high correlation coefficients [24].

Table 3. Correlation coefficient for the elements in $\mathrm{PM}_{10}$

\begin{tabular}{|c|c|c|c|c|c|c|c|c|c|c|c|c|c|c|c|c|c|c|c|c|}
\hline Elem & $\mathrm{Al}$ & $\mathrm{Ca}$ & $\mathrm{Cr}$ & $\mathrm{Cu}$ & $\mathrm{Mg}$ & $\mathrm{Fe}$ & $\mathrm{Li}$ & $\mathrm{Mn}$ & $\mathrm{Sr}$ & $\mathrm{Ti}$ & $\mathrm{Zn}$ & $\mathrm{Na}$ & $\mathrm{K}$ & $\mathrm{B}$ & $\mathrm{S}$ & $\mathrm{Sb}$ & $\mathrm{Co}$ & $\mathrm{Mo}$ & $\mathrm{Ni}$ & $\mathrm{V}$ \\
\hline $\mathrm{Al}$ & 1 & -0.25 & 0.04 & -0.02 & 0.09 & 0.13 & -0.06 & 0.03 & 0.01 & 0.03 & 0.93 & -0.28 & 0.33 & -0.26 & -0.11 & -0.15 & 0.28 & -0.33 & 0.88 & -0.9 \\
\hline $\mathrm{Ca}$ & & 1 & -0.22 & 0.33 & 0.95 & 0.1 & -0.24 & 0.75 & 0.98 & 0.13 & 0.78 & 0.78 & 0.32 & -0.42 & -0.91 & 0.08 & 0.83 & -0.59 & 0.83 & -0.49 \\
\hline $\mathrm{Cr}$ & & & 1 & -0.58 & -0.51 & 0.33 & -0.6 & -0.3 & -0.7 & 0.52 & -0.09 & -0.08 & -0.86 & -0.29 & 0.91 & -0.24 & 0.51 & 0.02 & 0.92 & -0.32 \\
\hline $\mathrm{Cu}$ & & & & 1 & 0.02 & -0.05 & 0.77 & -0.1 & 0.21 & -0.29 & -0.32 & -0.39 & 0.79 & 0.82 & -0.45 & -0.48 & 0.13 & -0.33 & -0.88 & 0.67 \\
\hline $\mathrm{Mg}$ & & & & & 1 & 0.44 & -0.05 & 0.87 & 0.88 & 0.14 & 0.77 & 0.76 & 0.24 & -0.45 & -0.92 & -0.03 & 0.09 & 0.26 & 0.3 & -0.55 \\
\hline $\mathrm{Fe}$ & & & & & 1 & -0.38 & 0.67 & 0.03 & 0.71 & 0.49 & 0.41 & -0.35 & -0.32 & -0.9 & -0.52 & 0.54 & 0.01 & 0.97 & -0.67 \\
\hline $\mathrm{Li}$ & & & & & & & 1 & -0.4 & 0.09 & -0.81 & -0.66 & -0.66 & 0.91 & 0.88 & -0.17 & -0.45 & -0.55 & 0.47 & -0.98 & 0.53 \\
\hline $\mathrm{Mn}$ & & & & & & & & 1 & 0.6 & 0.44 & 0.78 & 0.74 & -0.07 & -0.54 & -0.96 & 0.13 & 0.2 & 0.08 & 0.94 & -0.85 \\
\hline $\mathrm{Sr}$ & & & & & & & & & 1 & -0.05 & 0.67 & 0.69 & 0.45 & -0.32 & -0.91 & 0.05 & 0.46 & -1 & 0.14 & -0.31 \\
\hline $\mathrm{Ti}$ & & & & & & & & & & 1 & 0.65 & 0.58 & -0.72 & -0.59 & -0.21 & 0.08 & 0.87 & -0.6 & 0.95 & -0.83 \\
\hline $\mathrm{Zn}$ & & & & & & & & & & 1 & 0.98 & -0.32 & -0.83 & -0.63 & 0.26 & 0.63 & -0.52 & 0.92 & -0.91 \\
\hline $\mathrm{Na}$ & & & & & & & & & & & 1 & -0.33 & -0.28 & -0.56 & 0.28 & 0.56 & -0.47 & 0.96 & -0.9 \\
\hline $\mathrm{K}$ & & & & & & & & & & & & & 1 & 0.08 & -0.61 & -0.23 & -0.53 & 0.27 & -0.99 & 0.19 \\
\hline $\mathrm{B}$ & & & & & & & & & & & & & & 1 & 0.15 & -0.41 & -0.34 & 0.24 & -0.99 & 0.96 \\
\hline $\mathrm{S}$ & & & & & & & & & & & & & & & 1 & -0.05 & - & - & - & -0.99 \\
\hline $\mathrm{Sb}$ & & & & & & & & & & & & & & & 1 & -0.3 & -0.98 & -1 & -0.32 \\
\hline $\mathrm{Co}$ & & & & & & & & & & & & & & & & 1 & -0.88 & 0.98 & -0.56 \\
\hline $\mathrm{Mo}$ & & & & & & & & & & & & & & & & & 1 & -0.18 & 0.37 \\
\hline $\mathrm{Ni}$ & & & & & & & & & & & & & & & & & & 1 & 0.7 \\
\hline $\mathrm{V}$ & & & & & & & & & & & & & & & & & & & \\
\hline
\end{tabular}

SEM-EDAX Analysis. Both size distribution and composition of atmospheric aerosol particulates were derived from the Scanning Electron Microscope Energy Dispersive X-ray Spectroscopy (SEM-EDAX) analyses for $\mathrm{PM}_{10}$ samples.

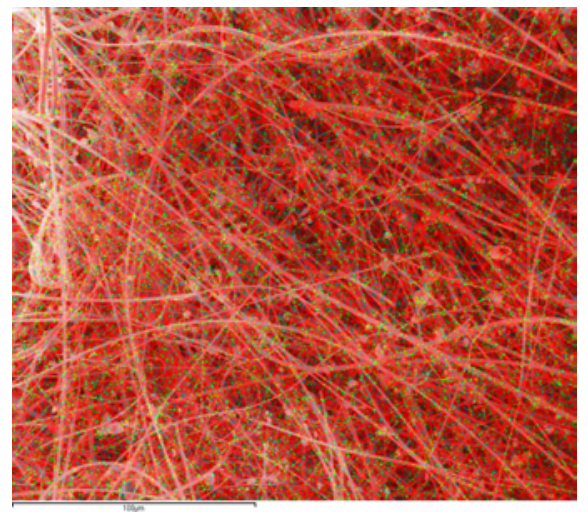

(a)

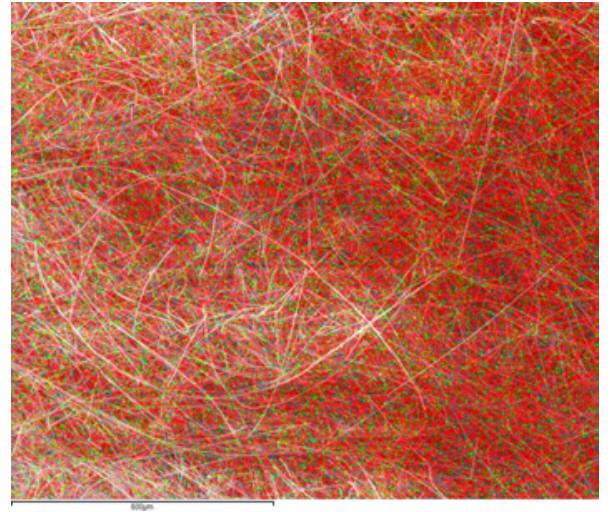

(b)

Figure 5. Distribution of silica (red) and alumina (green) (a) and Distribution of silica (red) and sodium (green) (b). 
Mass concentrations and elemental composition of atmospheric aerosols in Addis Ababa 371

Table 4. Relative percentage of elements in $\mathrm{PM}_{10}$ samples.

\begin{tabular}{|c|c|c|c|c|c|c|}
\hline \multirow[t]{2}{*}{ Element } & \multicolumn{6}{|c|}{ Sampling Site } \\
\hline & NSLP & KoKCC & KWWT & KSUB $^{*}$ & ATSE & STAD \\
\hline $\mathrm{Na}$ & $4.97 \pm 0.33$ & $5.82 \pm 1.04$ & $7.37 \pm 0.73$ & 5.77 & $5.43 \pm 0.04$ & 5.59 \\
\hline $\mathrm{Mg}$ & $0.073 \pm 0.06$ & $0.205 \pm 0.049$ & $0.32 \pm 0.03$ & 0.24 & $0.165 \pm 0.0002$ & 0.18 \\
\hline $\mathrm{Al}$ & $2.02 \pm 0.24$ & $2.4 \pm 0.35$ & $3.3 \pm 0.4$ & 2.26 & $2.09 \pm 0.003$ & 2.14 \\
\hline $\mathrm{Si}$ & $18.3 \pm 1.8$ & $19.5 \pm 3.1$ & $27.4 \pm 3.2$ & 19.8 & $17.8 \pm 0.4$ & 18.8 \\
\hline $\mathrm{Cl}$ & $0.14 \pm 0.22$ & $0.035 \pm 0.048$ & $\mathrm{ND}$ & 0.11 & $0.085 \pm 0.0001$ & ND \\
\hline $\mathrm{K}$ & $1.78 \pm 0.22$ & $1.62 \pm 0.21$ & $2.5 \pm 0.28$ & 1.76 & $1.69 \pm 0.01$ & 1.71 \\
\hline $\mathrm{Ca}$ & $1.02 \pm 0.09$ & $1.04 \pm 0.12$ & $1.52 \pm 0.18$ & 1.16 & $1.07 \pm 0.0004$ & 1.15 \\
\hline $\mathrm{Zn}$ & $2.59 \pm 0.06$ & $2.23 \pm 0.31$ & $3.52 \pm 0.37$ & 2.49 & $2.69 \pm 0.04$ & 2.39 \\
\hline $\mathrm{Ba}$ & $3.4 \pm 0.42$ & $2.86 \pm 0.17$ & $4.6 \pm 0.4$ & 3.14 & $3.2 \pm 0.03$ & 3.11 \\
\hline $\mathrm{O}$ & $54.9 \pm 1.5$ & $54.2 \pm 2.7$ & $46.6 \pm 2.7$ & 53.6 & $54.9 \pm 0.7$ & 54.6 \\
\hline $\mathrm{Fe}$ & $0.10 \pm 0.13$ & $0.14 \pm 0.01$ & $0.17 \pm 0.02$ & 0.11 & $0.065 \pm 0.004$ & ND \\
\hline $\mathrm{C}$ & $10.7 \pm 1.5$ & $9.7 \pm 2.74$ & $2.71 \pm 3.8$ & 9.41 & $10.8 \pm 0.37$ & 10.3 \\
\hline $\mathrm{Cu}$ & ND & $0.205 \pm 0.08$ & $0.09 \pm 0.13$ & 0.11 & ND & ND \\
\hline
\end{tabular}

Shows a single spectrum analysis result.
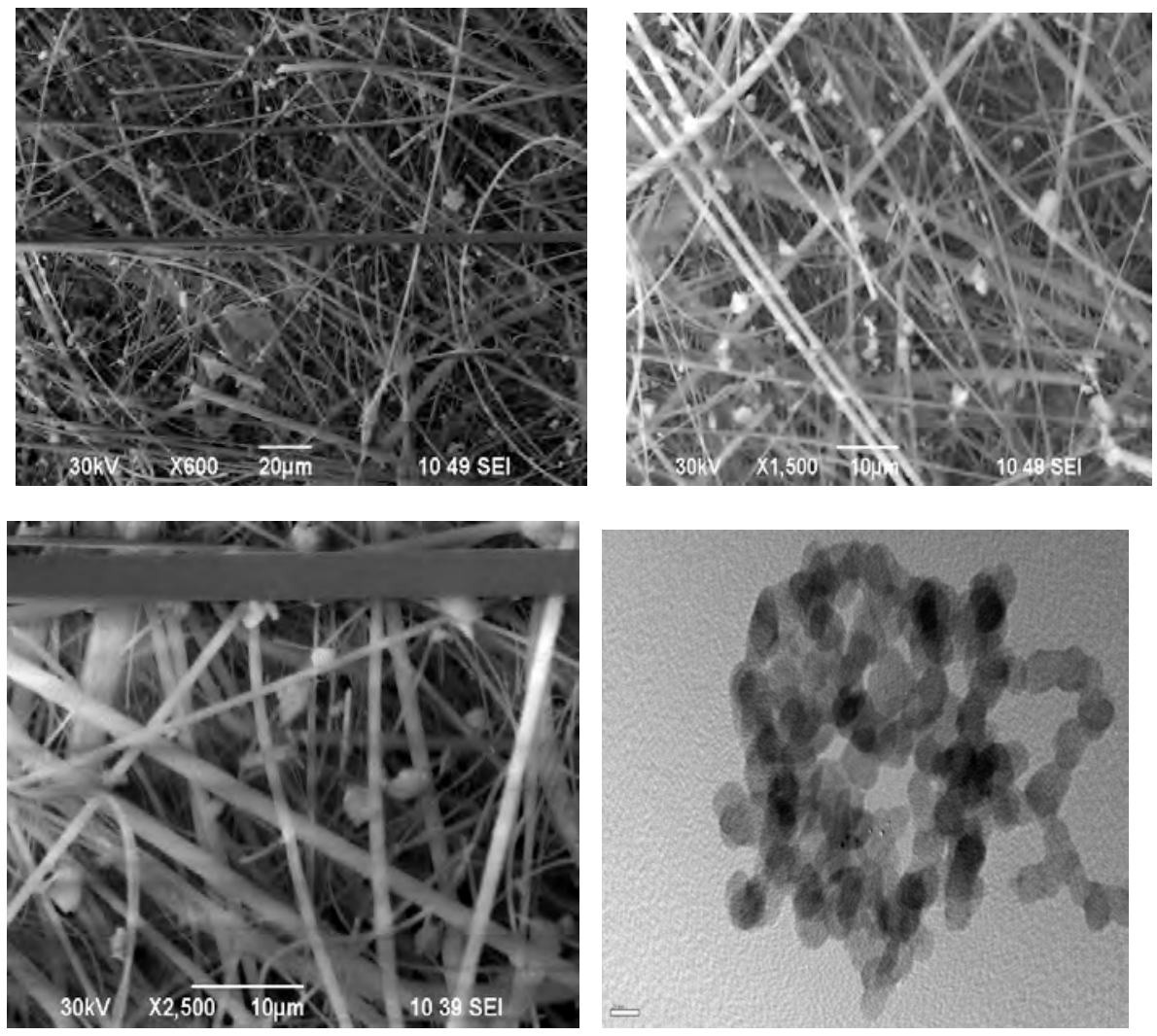

Figure 6. SEM image of size distribution of particulate matter of aerosol samples on the filter. 
Representative SEM-EDAX images indicating the relative distribution of elements on the filter samples, silica (red) and alumina (green) and silica (red) and sodium (green) are shown in Figure $5 \mathrm{a}$ and $5 \mathrm{~b}$, respectively. It can be seen that silica is predominant compared to aluminium and sodium which suggests abundance of alumino-silicate dust particles. Furthermore, result of elemental composition using SEM-EDAX analysis is shown in Table 4. The result also confirms that $\mathrm{Si}, \mathrm{Al}, \mathrm{Na}, \mathrm{Zn}, \mathrm{Ba}, \mathrm{K}$ and $\mathrm{C}$ are the predominant species. Crustal materials contributed from 76 to $95 \%$ and the contribution of $\mathrm{C}$ and $\mathrm{Cu}$ was in the range between 5 and $24 \%$. The high proportion of $\mathrm{Si}, \mathrm{Ca}, \mathrm{Na}$, and $\mathrm{K}$ in the filter samples suggests the aerosols are predominately originated from geological sources. The presence of $\mathrm{C}$ on the filter samples can possibly be attributed to biomass combustion, fossil fuel combustion, and waste burning activities.

The size distribution of particulates for a representative samples is shown in Figure 6. The size distribution of aerosol particles as derived from SEM analysis for all sampling sites was in $0.43-9.3 \mu \mathrm{m}$ range and it is also observed that $47 \%$ of the particles have an average diameter less than 2.5 micrometer. The SEM micrograph of the filter mass shows that, most of the particles possess spherical and circular shape.

\section{CONCLUSIONS}

The levels of atmospheric aerosols were determined at seven urban and peri-urban sites of Addis Ababa, Ethiopia. The major findings of this study based on samples collected during dry and wet seasons of 2008 showed that the mean TSP concentration of Addis Ababa was 195 \pm $141 \mu \mathrm{g} / \mathrm{m}^{3}$. The highest and lowest values were $556 \mu \mathrm{g} / \mathrm{m}^{3}$ (Feb. 2008 at NSLP site) and 17 $\mu \mathrm{g} / \mathrm{m}^{3}$ (June 2008 at KSUB), respectively. The mean TSP value surpassed the lower limit of WHO safe guideline value of $150-230 \mu \mathrm{g} / \mathrm{m}^{3}$ [30]. The mean $\mathrm{PM}_{10}$ mass of Addis Ababa was $80 \pm 61 \mu \mathrm{g} / \mathrm{m}^{3}$. The maximum and minimum values were $285 \mu \mathrm{g} / \mathrm{m}^{3}$ (Feb. 2008 at KWWT) and $17 \mu \mathrm{g} / \mathrm{m}^{3}$ (July 2000 at COLTI), respectively. $79 \%$ of the $\mathrm{PM}_{10}$ values were below the 24-h Ethiopian EPA and WHO guideline values. The mean values of $\mathrm{PM}_{10}$ of Addis Ababa were found to be higher than that reported for most European cities. The mean PM10 to TSP mass ratio was in the range of 0.26 to 0.67 and the $\mathrm{PM}_{10}$ mass contributed about $42 \%$ of the TSP mass. The remaining portion may be attributed to fine particulates. ICP analysis of $\mathrm{PM}_{10}$ samples showed that $\mathrm{Al}, \mathrm{B}, \mathrm{Ca}, \mathrm{Cd}, \mathrm{Co}, \mathrm{Cr}, \mathrm{Cu}, \mathrm{Fe}, \mathrm{K}, \mathrm{Li}, \mathrm{Mg}, \mathrm{Mn}, \mathrm{Mo}, \mathrm{Na}, \mathrm{Ni}, \mathrm{S}, \mathrm{Sb}, \mathrm{Sr}, \mathrm{Ti}, \mathrm{V}$ and $\mathrm{Zn}$ were identified. The average element concentration order was $\mathrm{Ca}>\mathrm{Na}>\mathrm{K}>\mathrm{Zn}>\mathrm{Sb}>$ $\mathrm{B}>\mathrm{Al}>\mathrm{V}>\mathrm{Mg}>\mathrm{S}>\mathrm{Fe}$. These elements contributed about $0.1 \%$ of the $\mathrm{PM}_{10}$ mass. The elements concentrations were far lower than those found in urban areas of Europe and Asia. SEM-EDAX analysis showed that $\mathrm{Si}, \mathrm{Al}, \mathrm{Na}, \mathrm{Zn}, \mathrm{Ba}, \mathrm{K}$ and $\mathrm{C}$ were the predominant components of the $\mathrm{PM}_{10}$ fractions. The analysis results revealed that, 76-95\% was of geological origin. The remaining 5-24\% was carbon compounds and small amount of $\mathrm{Cu}$. The presence of carbon in the samples may be due to incomplete combustion of fossil fuels and biomass around the sampling sites. The size distribution of aerosol particles from SEM analysis was in 0.43-9.3 $\mu \mathrm{m}$ ranges. While the present work provides an insight regarding the level of TSP and $\mathrm{PM}_{10}$ mass concentration and their composition in Addis Ababa, further studies will be needed to characterize $\mathrm{PM}_{10}$ and $\mathrm{PM}_{2.5}$ (including ionic species, $\mathrm{EC}$, OC and VOCs) with more sampling coverage. In addition, meteorological conditions such as wind speed, wind direction, precipitation and relative humidity need to be determined on continuous basis.

\section{REFERENCES}

1. Etyemezian, V.; Tesfaye, M.; Yimer, A.; Chow, J.C.; Mesfin, D.; Nega, T.; Nikolich, G.; Watson, J.G.; Wondmagegn, M. Atmos. Environ. 2005, 39, 7849.

2. Central Statistics Authority of Ethiopia (CSA) Population and housing census of Ethiopia, Statistical Abstract, 1994.

Bull. Chem. Soc. Ethiop. 2010, 24(3) 
Mass concentrations and elemental composition of atmospheric aerosols in Addis Ababa 373

3. Kume, A. Ph.D. Thesis, Addis Ababa University, Ethiopia, 2009.

4. De Koning, H.W.; Kretzschmar, J.G.; Akland, G.G.; Bennett, B.G. Atmos. Environ. 1986, 20, 101.

5. Dockery, D.W.; Pope III, C.A.; Xu, X.; Spengler, J.D.; Ware, J.H.; Fay, M.E.; Ferris Jr., B.G.; Speizer, F.E. New England J. Med. 1993, 329, 1753.

6. Reichhardt, T. Environ. Sci. Technol. 1995, 29, 360.

7. Pope III, C.A.; Dockery, D.W.; Schwartz, J. Inhalation Toxicology 1995, 7, 1.

8. Pope, C.A.; Dockery, D.W. J. Air Waste Manage. Assoc. 2006, 56, 709.

9. Pope, C.A.; Burnett, R.T.; Thurston, G.D.; Thun, M.J.; Calle, E.E.; Krewski, D.; Godleski, J.J. Circulation 2004, 109, 71.

10. Pope, C.; Burnet, R.; Thun, M.J.; Calle, E.E.; Krewski, D.; Ito, K.; Thurston, G.D. J. Am. Med. Assoc. 2002, 287, 1132.

11. Dockery, D.W.; Stone, P.H. New England J. Med. 2007, 356, 511.

12. Donaldson, K.; MacNee, W. Intern. Hygiene Environ. Health 2001, 203, 411.

13. IPCC in Climate Change, Houghton, J.T.; Ding, Y.; Griggs, D.J.; Noguer, M.; van der Linden, P.J.; Dai, X.; Maskell, K.; Johnson, C.A. (Eds.), Cambridge University Press: Cambridge, UK; 2001.

14. Morawska, L.; Thomas, S.; Bofinger, N.; Wainwright, D.; Neale, D. Atmos. Environ. 1998, 32, 2467.

15. Weisel, C.P. Environ. Health Perspect 2002, 110 (suppl 4), 527.

16. Zhou, W.; Yuan, D.; Ye, S.; Qi, P.; Fu, C.; Christiani, D.C. Int. J. Occup. Environ. Health 2001, 7, 23.

17. Harris, S.J.; Maricq, M.M. J. Aerosol Sci. 2001, 32, 749.

18. Guo, Y.L.; Lin, Y.C.; Sung, F.C.; Huang, S.L.; Ko, Y.C.; Lai, J.S.; Su, H.J.; Shaw, C.K.; Lin, R.S.; Dockery, D.W. Environ. Health Prospect 1999, 10, 1001.

19. Artinano, B.; Salvator, P.; Alonso, D.G.; Querol, X.; Alastuey, A. Environ. Poll. 2003, 125, 453.

20. Tsai, Y.I.; Cheng, M.T. Chemosphere 2004, 54, 1171.

21. Drewnick, F.; Schwab, J.J.; Jayne, J.T.; Canagaratna, M.; Worsnop, D.R.; Demerjian, K.L.; Aerosol Sci. Technol. 2004, 38, 92.

22. Rodrı'guez, S.; Van Dingenen, R.; Putaud, J.P.; Dell'Acqua, A.; Pey, J.; Querol, X.; Alastuey, A.; Chenery, S.; Ho, K.F.; Harrison, R.; Tardivo, R.; Scarnato, B.; Gemelli, V. Atmos. Chem. Phys. 2007, 7, 2217.

23. Ghermandi, G.; Laj, P.; Capotosto, M.; Cecchi,R.; Riontino, C. Nuclear Instruments and Methods in Physics Research B 1999, 150, 392.

24. Wojas, B.; Almquist, C. Atmos. Environ. 2007, 41, 9064.

25. Yusoff, M., Rashid, M., Symposium of Malaysian Chemical Engineers, Kuala Lumpur, Malaysia; 1987; pp 1-16.

26. Lippmann, M.; Ito, K.; Nádas, A.; Burnett, R.T. Health Effects Institute Research Report Number 95, 2000.

27. Begum, B.A.; Kim, E.; Biswas, S.K.; Hopke, P.K. Atmos. Environ. 2004, 38, 3025.

28. Watson, J.G.; Chow, J.C.; Rogers, C.F.; DuBois, D.; Cahill, C. Report, prepared for the California Regional Particulate Air Quality Study, California Air Resources Board, Sacramento, Desert Research Institute, 1997.

29. Hueglina, C.; Gehriga, R.; Baltenspergerb, U.; Gyselc, M.; Monnd, C.; Vonmonta, H. Atmos. Environ. 2005, 39, 637.

30. World Health Organization Ambient Air Quality Guideline, World Health Organization: Geneva; 2005. 